\title{
Leading by listening, learning by doing: modeling democratic approaches to conservation leadership in graduate education
}

\author{
Karen A. Kainer ${ }^{1,2}$ (D) Citlalli López Binnqüist ${ }^{3}$. Jonathan L. Dain ${ }^{1}$. Belinda Contreras Jaimes ${ }^{3,4}$. \\ Patricia Negreros Castillo ${ }^{5}$ • Roldan Gonzalez Basulto ${ }^{3,6}$ • Edward A. Ellis ${ }^{3}$ • Hannah H. Covert ${ }^{1}$. \\ Rodrigo López Rodríguez ${ }^{3,7}$ • Irving Uriel Hernández Gómez ${ }^{3,8}$ • Fernando Melchor Contreras ${ }^{3,9}$
}

Published online: 5 March 2019

(C) The Author(s) 2019

\begin{abstract}
Conservation professionals are increasingly called on to adopt democratic approaches that integrate public concerns and diverse societal voices yet are not taught how to do so. We use a case study approach to analyze a 3-year graduate learning initiative piloted in Mexico by Universidad Veracruzana and the University of Florida that sought to fill this gap. Two team-taught courses were integrated with multiple field and on-campus experiences (e.g., stakeholder simulations, community dissemination events, scholar-practitioner workshops, a student exchange forum), pedagogically modeling the collaborative leadership needed to address current conservation challenges. Our analysis highlights individual student and institutional impacts, drawing on systematic reflections, an external evaluation, and a student survey administered 3 years after the initiative ended. Through methodical learning opportunities, students incrementally and systematically developed skills and confidence. Their conceptualization of leadership shifted as they preferentially referred to themselves as agents of change (versus leaders), working across disciplines and collectively with multiple social actors. Students highlighted the following learning impacts: the strength of diversity across disciplines and individuals, individual and collective learning, intertwined professional and personal growth, and a new concept of conservation leadership. The university-to-university collaboration continues through multiple joint activities. Maintaining institutional support and instigating administrative change toward a democratization of educational processes is a slow and delicate proposition, yet it occurred. Finally, we emphasize integration of training to manage conflict and collaboration into conservation education as well as constant reflection to appropriately redirect programs.
\end{abstract}

Keywords Collective learning · Conflict management $\cdot$ Conservation practice $\cdot$ Experiential learning · Interdisciplinary education $\cdot$ Student diversity

Karen A. Kainer

kkainer@ufl.edu

1 Tropical Conservation and Development Program, Center for Latin American Studies, University of Florida, 319 Grinter Hall, Gainesville, FL 32611-5530, USA

2 School of Forest Resources and Conservation, University of Florida, 210 Newins-Ziegler Hall, Gainesville, FL 32611-0410, USA

3 Centro de Investigaciones Tropicales, Universidad Veracruzana, José María Morelos 44, Zona Centro, Centro, C.P. 91000 Xalapa Enríquez, Veracruz, Mexico

4 Present address: Escuela Nacional de Estudios Superiores Unidad Morelia, Universidad Nacional Autónoma de México, Antigua Carretera a Pátzcuaro 8701, Col. Ex Hacienda de San José de la Huerta, C.P. 58190 Morelia, Michoacán, Mexico
5 Present address: Academia Nacional de Ciencias Forestales, Calle Beta 109, Col. Romero de Terreros, Coyoacán, Ciudad de México C.P. 04310, Mexico

6 Present address: Escuela Secundaria Mixta U 30, Calle 8 No. 1526, Col. Ferrocarril, C.P. 44440 Guadalajara, Jalisco, Mexico

7 Present address: Asociación Civil Agencia para el Desarrollo Local Tatatila A.C. con Carretera Federal San Andres Tuxtla-Catemaco, Km 145, Veracruz, Mexico

8 Present address: Facultad de Ciencias Agrícolas, Universidad Veracruzana, Circuito Gonzalo Aguirre Beltrán, Isleta, C.P. 91090 Xalapa Enríquez, Veracruz, Mexico

9 Present address: Instituto Tecnológico de Úrsulo Galvan, Extension Tlapacoyan, Prolongación Abasolo s/n, Colonia Manuel Antonia Ferrer, C.P. 9360 Tlapacoyan, Veracruz, Mexico 


\section{Introduction}

In the last three decades, conceptualization of biodiversity conservation has broadened dramatically. While protected areas continue to be a cornerstone of conservation policy, there is much greater appreciation of the larger, often actively managed rural landscapes in which protected areas are embedded. This expanded view implies that thoughtful engagement of those who occupy, manage, and have a stake in that landscape is necessary for lasting conservation to occur. As a result, biodiversity conservation has appropriately shifted from narrowly focused command and control approaches (Holling \& Meffe 1996) to ones that integrate public concerns, incorporate a wide spectrum of societal voices, and foster linkages between science and policy (Bawa et al. 2004) - approaches that are more democratic. While there is consensus that this shift needs to occur, conservation leaders and the graduate education programs that train them are rarely equipped to address this expanded mission. Using a case study methodology, we report on a 3-year graduate-level education initiative that set out to address these conservation leadership concerns. Written from the perspective of participating faculty and students, our case analysis aims (1) to describe the rationale behind, and implementation of, a pedagogical approach to conservation leadership development and (2) to explain the initiative's impacts on participating students and institutions.

\section{Democratic approaches and conservation leadership}

To date, conservation leadership has largely centered on "shaping conservation science through path-breaking research" (Manolis et al. 2008, p. 881). This leadership emphasis has been highly effective, explaining why conservation biology as a discipline has grown so dramatically and made such positive strides for understanding the science of conserving Earth's biodiversity (Meffe et al. 2006). In contrast to this scholarly growth, however, impact on the actual conservation of biodiversity has paled (Meffe et al. 2006). This suggests that a new kind of conservation leadership is needed - one that integrates listening to different stakeholders, effective public engagement and deliberation on complex conservation questions, and the creation of adequate, equal, and trusted processes for decision-making. We need leaders that embrace a "democratization" of conservation, which we define as the ongoing process of enhancing and enabling the engagement of different voices and views for the benefit of conservation. Indeed, the untapped power and possibilities of this type of leadership is captured by Manolis et al. (2008) when they describe it as the "new frontier in conservation science."

\section{Conservation training at the graduate level: an already full plate}

The call to make graduate education more responsive to realworld conservation needs is not new; numerous graduate programs have emerged from this demand (Vincent and Focht 2011). Higher education tendencies toward biotechnology, privatization, and specialization challenge graduate programs to emphasize applied research and practice for conservation problem solving - precisely what has been called for in Mexico since the 1990s (Moreno-Casasola and Sánchez Ríos 1990; Camou Guerrero et al. 2013). Conservation organizations have long expressed the need for graduates with greater communication skills and the ability to explain biodiversity science and values to the lay public, coupled with interpersonal skills and the ability to work in groups (Cannon et al. 1996). Pérez (2005) identified essential "professional skills" such as problem solving, analysis of regulations and policy, conflict resolution, and stakeholder relations. Related, but distinct, is the call for greater integration of the social sciences into graduate conservation curricula (Fisher et al. 2009) with cross-departmental, interdisciplinary and transdisciplinary training (Gosselin et al. 2016). The relevance of social research to conservation is now widely accepted (Sandbrook et al. 2013; Moon and Blackman 2014), though integration of social insights and social scientists themselves into the actual management of ecosystems continues to challenge conservation organizations (Mascia et al. 2003; Sievanen et al. 2012) still dominated by professionals trained in the natural and environmental sciences (Bonine et al. 2003). How can academia respond to the "consistent message that graduate education does not currently provide students with the skills they need to solve conservation problems" (Muir and Schwartz (2009, p. 1358)? How can universities develop conservation leadership that "extends beyond the research community and changes the way policy makers, managers, citizens, and scientists interact with research and each other" (Manolis et al. 2008, p. 881)? What kind of training approaches might better bridge the oft-identified research-implementation gap (Courter 2012; Pietri et al. 2013; Toomey, 2016), and without sacrificing disciplinary depth in an already full curriculum (Kainer et al. 2006)?

\section{Methodological approach}

We adopt a case study approach to reveal in-depth knowledge of a single conservation education initiative with concentrated activities from 2010 to 2013 (Fig. 1). Because this case is not representative of all conservation education initiatives, we acknowledge that our findings herein do not lead to generalizable results. Nonetheless, departing from context-independent facts and rules, which only generate beginner-level understanding (Flyvbjerg 2006), our intent is to contribute specific case details so that other conservation educators can assess 

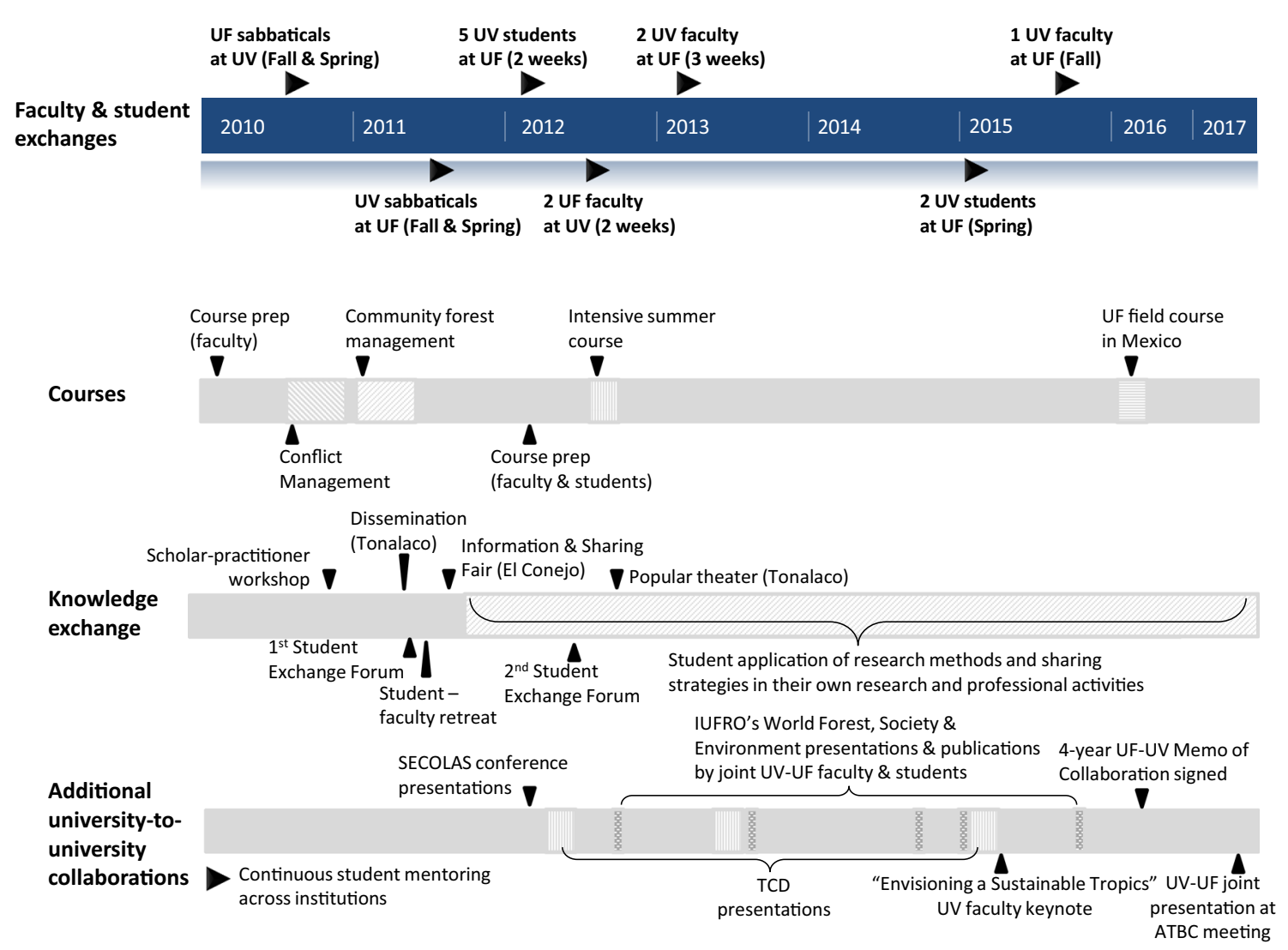

Fig. 1 Timeline of faculty and student exchanges between the Universidad Veracruzana and the University of Florida. Courses and knowledge exchange in Mexico are highlighted as well as additional university-to-university collaborations that extended well beyond the end of grant funding in November 2012. IUFRO = International Union of Forest Research Organizations, ATBC $=$ Association for Tropical Biology and Conservation

institutional impacts at multiple time points, typically after initiative-sponsored events, but also in periodic reflection retreats. We compared new reflections and themes generated at each reflection time point to previously generated reflections. This allowed us to treat the data as a whole (versus fragments considered on their own) (Anderson 2010) and to analytically reduce themes on an ongoing basis. Themes were triangulated with student-only reflections (Fig. 2), the student survey, and the external evaluation report, resulting in four main themes for student impacts and two themes for institutional impacts. For institutional impacts, 8 years have transpired since the launching of this initiative, theoretically permitting a reasonable assessment of what has been maintained institutionally, although enduring institutional change can only be detected over decades.

\section{The Education Initiative}

\section{Initiative context}

This pedagogical opportunity emerged when the Universidad Veracruzana (UV) and the University of Florida (UF) 
Table 1 Systematic moments of collective reflection by co-authors over the course of the initiative

\begin{tabular}{|c|c|c|c|c|}
\hline $\begin{array}{l}\text { Year } \\
\text { Semester }\end{array}$ & Event & Event participants & Type of documentation & Co-authors who collected data \\
\hline $\begin{array}{r}2010 \\
\text { Fall }\end{array}$ & Monthly planning and reflections & $4-5$ faculty & Meeting notes, HED reports & Faculty \\
\hline Fall & Conflict Management student evaluation & 2 faculty, 40 students & Oral evaluation notes & Faculty \\
\hline Fall & Scholar-practitioner workshop evaluation & 4 faculty, 10 students & Workshop evaluation instrument & Faculty \\
\hline $\begin{array}{l}2011 \\
\text { Spring }\end{array}$ & Monthly planning and reflections & $4-5$ faculty & Meeting notes, HED reports & Faculty \\
\hline Spring & $\begin{array}{l}\text { Community Forest Management student } \\
\text { evaluation }\end{array}$ & 2 faculty & Oral evaluation notes & Faculty \\
\hline Spring & Student-faculty retreat & 5 faculty, 10 students & Meeting notes & Faculty and students \\
\hline Spring & 1st Student Exchange Forum & 35 students & Planning and debrief documents & Students \\
\hline Summer & Faculty retreat & 5 faculty & Meeting notes, HED reports & Faculty \\
\hline Fall & Faculty retreat & 6 faculty & Meeting notes, HED reports & Faculty \\
\hline Fall & LATAM colloquium on TIES project & 6 faculty & Preparatory notes, presentation & Faculty \\
\hline $\begin{array}{l}2012 \\
\text { Spring }\end{array}$ & SECOLAS conference & 5 students & Internal report, conference presentation & Students \\
\hline Spring & Student-faculty retreat & 6 faculty, 5 students & Meeting notes & Faculty and students \\
\hline Spring & 2nd Student Exchange Forum & 32 students & Planning and debrief documents, student video & Students \\
\hline Summer & Faculty retreat & 5 faculty & Meeting notes; TIES reports & Faculty \\
\hline Summer & Intensive summer course evaluation & 5 faculty, 13 students & Oral evaluation notes & Faculty and students \\
\hline $\begin{array}{l}2015 \\
\text { Spring }\end{array}$ & Student assessment of education initiative & 5 students & Survey via email & students \\
\hline Fall & Faculty retreat & 3 faculty & Meeting notes & Faculty \\
\hline $\begin{array}{l}2016 \\
\text { Spring }\end{array}$ & Planning meeting for collaborative agreement & 5 faculty & $\begin{array}{l}\text { Meeting notes, proposed activities document, } \\
\text { collaborative agreement }\end{array}$ & Faculty \\
\hline $\begin{array}{l}2017 \\
\text { Summer }\end{array}$ & ATCB conference panel & 2 faculty & Presentation and abstract & Faculty \\
\hline
\end{tabular}

HED Higher Education for Development Program of the U.S. Agency for International Development, LATAM Center for Latin American Studies, University of Florida, SECOLAS Southeast Council of Latin American Studies Conference, ATBC Association for Tropical Biology and Conservation

established a partnership funded by the Higher Education for Development Program of USAID, specifically to support training, internships, exchanges, and scholarships (TIES) in
Mexico. We had additional support via Fulbright Scholar grants. Both universities have graduate programs that bridge traditional academic boundaries and emphasize applied
Fig. 2 Adapted version of the summary diagram of student initiative reflections presented at the 2012 Southeast Council of Latin American Studies (SECOLAS) Conference, Gainesville, Florida. Nine welltargeted educational innovations were highlighted in the diagram and detailed in an accompanying internal report in terms of the educational strategy, the teachinglearning process, the didactic style, and the building of individual capacities

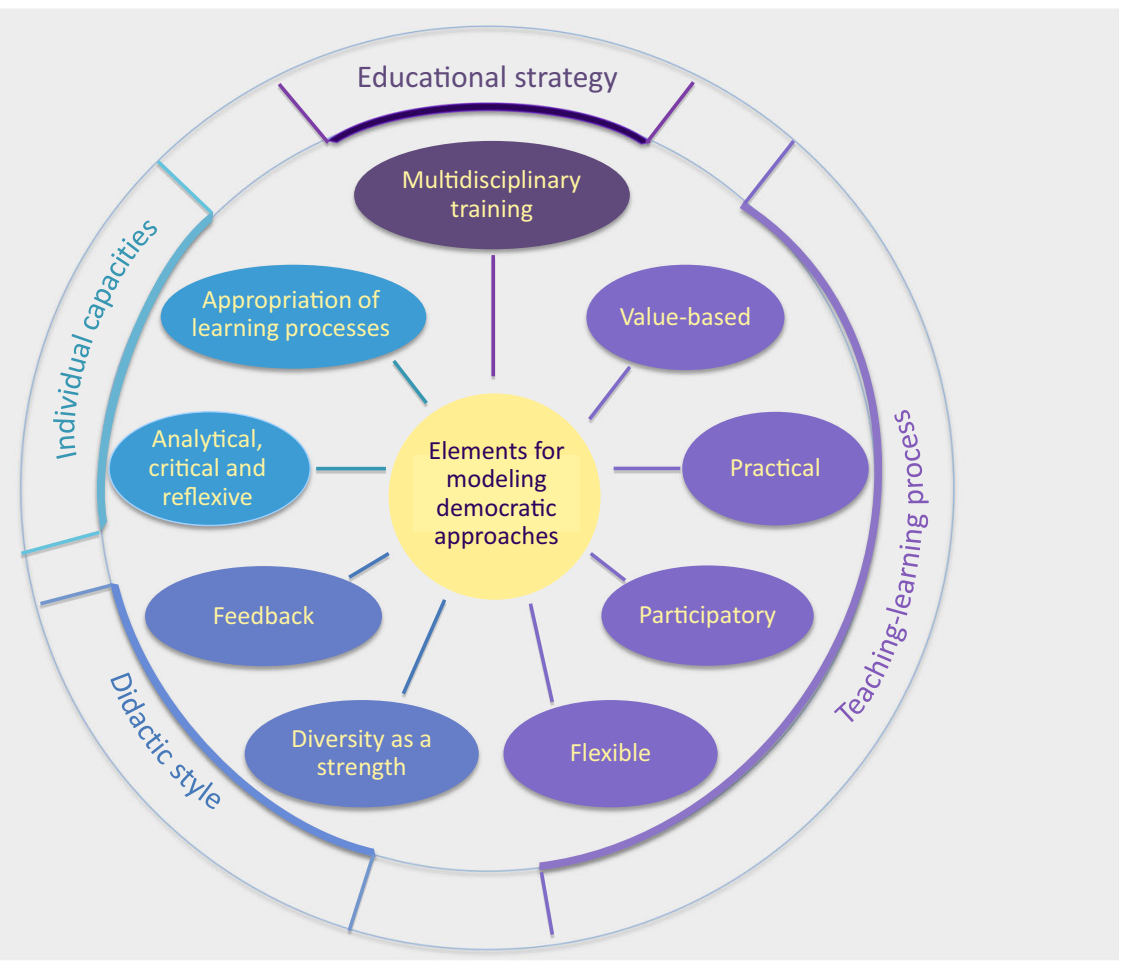


research for conservation goals: Center for Tropical Research (CITRO) at UV and the Tropical Conservation and Development Program (TCD) at UF. Key initiative objectives were (1) to construct a novel, tailored educational approach to training conservation leaders at CITRO and (2) to use these learning opportunities to expand UV-CITRO's influence on regional conservation and sustainable use. For decades, UF's TCD Program has worked to train graduate-level professionals to learn across disciplines and to bridge theory and practice (Kainer et al. 2006). Our initiative did not seek to replicate the TCD model, but rather, to take that experience and embrace the characteristics and conditions at CITRO to innovate and reflect on conservation education.

The pedagogical team consisted of six (four female, two male) faculty members: three UV faculty specialized in anthropology, geomatic applications to natural resource management, and silviculture and three UF faculty specialized in community forestry, socio-environmental conflict management, and international education and higher education administration. The team targeted the incoming 2010-2011 cohort of 23 CITRO graduate students and two recent graduates of UV's Intercultural University. The students came from rural and urban environments, some with significant work experience and others straight out of undergraduate programs. The majority were male (64\%) and had educational backgrounds in the biological or agronomic sciences $(72 \%)$. Undergraduate degrees in education, geography, law, and intercultural development also were represented. This diverse student-faculty group constituted the primary interactive domain of the initiative, shaped by day-to-day interactions inside and outside the classroom, and served as the anchor for practical and analytical exercises. The diversity of the group served as a platform to construct and reflect on distinct contexts and experiences, deconstruct and manage group dynamics, critically deal with power differentials and hierarchies, and learn how to listen to others and reach collective decisions.

\section{Pedagogical approach}

Our pedagogical approach focused on the following elements: (1) probe key concepts, build practical skills, acknowledge values, and embrace supportive attitudes and (2) model collaborative leadership in our own pedagogy and governance. We considered the often-competing substantive, procedural, and psychological interests (Moore 2014) held by students, faculty, and administrators. The substantive interests or pedagogical content focused on new theoretical and conceptual knowledge, critical analytical and practical skills, and a suite of attitudes (Table 2). These targeted interests complement the fundamental content typically embraced within graduate education (e.g., defining a research question, completing a thesis). Procedural interests (a fair process and equitable access to relevant information) and psychological interests (feeling respected and trusted), however, are equally important for effective learning (Moore 2014) and critical for developing this new type of conservation leadership. To this end, we modeled pedagogical philosophies and learning environments that engage and foster co-learning with diverse stakeholders. Faculty explicitly demonstrated ways that professors from different disciplines, and from the Global South and North, could work together collaboratively. We approached students as partners in learning and incorporated their knowledge and experiences into activities and programmatic decisions, attempting to mediate the power imbalances that exist between faculty and students. As Paulo Freire (1970) might have suggested: How will future conservation leaders learn to think of others as partners, if faculty treat students as subjects requiring deposits of knowledge? This pedagogical approach mimics the type of democratic approaches needed to address current conservation challenges. We created continuous opportunities for both faculty and students to reflect over the course of the initiative (Fig. 1), because individuals learn from experiences through reflection (Kolb 1984). Finally, expanding beyond the primary student-faculty interactive domain, we included practical field experiences with diverse groups of stakeholders (e.g., farmers, researchers, and government employees), thrusting students into the "real-world" conservation environment where they were obliged to consider multiple perspectives and ways of communicating.

\section{Activities and incremental learning}

For the first year (Academic Year 2010-2011; Fig. 1), two sequential courses were team-taught by UV-UF professors, providing a foundational structure typical of universities. Socio-environmental Conflict Management and Community Forest Management created recognizable accepted spaces for interactions between faculty and students. Familiar learning techniques (Table 2) were practiced in the classroom and in the field. Field activities were carried out in two ejidos (communally managed land areas) in and around nearby National Park Cofre de Perote, providing living case studies with contrasting access to forest resources and development options. Visible from campus, the national park has a long history of local peoples residing within and around its borders, practicing subsistence agriculture and relying heavily on forest resources (García-Romero et al. 2010; CONANP 2015). With faculty support, groups of students completed course field components and interwoven complementary activities throughout the education initiative (Table 2 and Fig. 1). The planned incremental nature of these activities and repeated practice of skills were intended to improve student self-confidence to engage with stakeholders internal and external to the university system. 


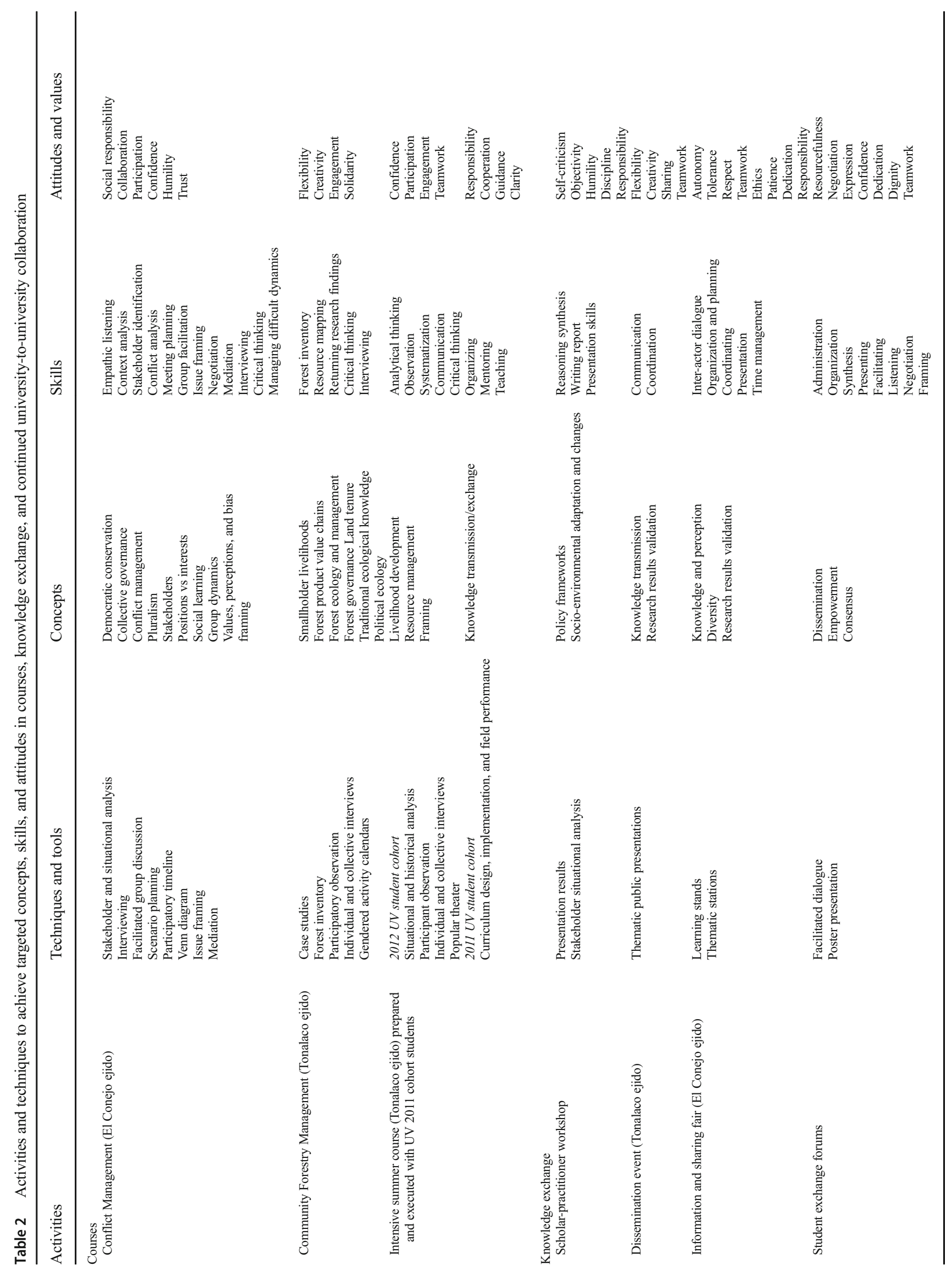


Socio-environmental Conflict Management combined stakeholder and situational analyses, planning tools, and concepts of pluralism with practical training in listening, facilitation, and negotiation (Table 2). Fieldwork was conducted in the community of El Conejo, located entirely inside the national park. The class received a guided visit from community members and then was assigned to one of six teams to interview and engage with a different community/park stakeholder group: potato farmers, women's artisan group, adolescents, researchers working in the area, protected area officials, and other government officials. Over the semester, student teams returned repeatedly to engage their designated stakeholder group, culminating in a half-day capstone "Scenarios Planning" workshop, whereby each team assumed the perspectives, needs, and interests of their particular stakeholder group. Teams engaged in a facilitated discussion and negotiation over how community development and park conservation needs might be balanced. The simulation highlighted the difficulty and necessity of identifying diverse stakeholder interests and values and of listening without prejudice to those with whom they might disagree. This experience constituted an important opportunity for self-reflection and confrontation, helping student to comprehend and analyze the shoes worn by others. Finally, the collective stakeholder results from this course were presented at a Scholar-Practitioner workshop (Fig. 1) to other professionals active in park research and engagement.

\section{Community forest management course}

This course emphasized working with local communities to manage forest ecosystems and resources. Modules focused on smallholder production systems and conceptual frameworks for understanding the broader sociopolitical and cultural contexts of forests, while also practicing diverse skills (Table 2). Students conducted group investigations of forest product value chains, such as ornamental orchids in local markets and green certified furniture. These investigations obliged students to interact with the multiple actors and markets that shape and constrain how communities benefit (or not) economically and socially from forest products originating from their lands. Like the Conflict Management course, the centerpiece of learning was student engagement with a local community, Tonalaco. Unlike El Conejo, Tonalaco includes lands outside the national park, permitting residents to manage their collective forests commercially for timber production and hydrological services. Over one weekend, students learned directly from Tonalaco residents how they use and manage their forests, govern their ejido, cultivate their milpa (agricultural field dominated by corn), and organize their households. Students conducted forest inventories jointly with community 
members, developing hands-on technical skills and experiencing the value in engaging with local people. With faculty backstopping, students formed three dissemination groups to convey and validate what they had learned to Tonalaco residents, reaching 240 primary school students, the Ejido Assembly composed of 64 men and 6 women, and an additional group of 80 women and children.

\section{Information and sharing fair}

The concept of returning research results resonated so strongly with the students that they held a subsequent dissemination event in El Conejo. Using their previous organizational experience in Tonalaco and with additional support from faculty and UV's community liaison, students organized an afternoon-long "Information and Sharing Fair" (Feria de Información y Convivio). Students set up four learning stations in the community's primary school, each with a different theme based on community needs identified during their coursework, stakeholder interviews, and affiliated research. Stations focused on (1) stakeholders' experiences and perceptions about the national park, (2) resident rights and challenges when living within the boundaries of a national park, (3) forest ecology and ecological services, and (4) environmental education activities for children. Over 400 ejido residents participated enthusiastically, rotating for $3 \mathrm{~h}$ through the learning stations. Community members commented that they felt that their work and roles in forest protection and management were recognized and valued and that they learned about forest policies and the historical context of national parks in Mexico. They critically noted that few previous researchers had returned to explain findings.

\section{Student research exchange forum}

Toward the end of the academic year, the faculty team introduced the idea of a research exchange forum, modeled after a similar activity conducted by UF's Center for Latin American Studies. The aim was to create a space whereby students could practice leadership, facilitation, and presentation skills, while sharing their research findings and broader graduate experiences. CITRO students organized the Forum into two parts: (1) a student-only session to discuss issues related to the research process and their graduate experiences and (2) a poster session, where students presented research posters to approximately 70 attendees, including faculty and students from UV academic units outside of CITRO. Students debated ideas, celebrated their accomplishments, and received feedback from peers, the broader campus community, and the general public.
Subsequent leadership development opportunities

After the 2010-2011 academic year, three additional student leadership development opportunities took place. Through a competitive process, five UV-CITRO students were selected to work with the UF-UV faculty team for 2 weeks on the UF campus in Spring 2012. In consultation with their cohort, these students analyzed the learning initiative based on their individual and collective experiences and presented their reflections at the Annual Southeast Council of Latin American Studies (SECOLAS) Conference. They chose to highlight what they considered to be nine key educational innovations implemented, as they stated, "with small, secure and clearly accompanied steps" (Fig. 2). Additionally, during their stay at UF, they interacted with professors, accessed library facilities, presented their thesis findings, and exchanged ideas with UF graduate students. They also committed to provide similar learning opportunities to the next CITRO student cohort, increasing the likelihood that the philosophical and practical learning approaches introduced within the project would continue. In addition, one UV-CITRO administrator visited UF during this period, attempting to solidify partnership-initiated activities and build the institutional support necessary for peer-to-peer learning and student-led initiatives so critical for long-term educational change (Duchelle et al. 2009).

Subsequent to the UF campus visit, an intensive 1-week Stakeholders and Natural Resources course took place in Summer 2012 (Fig. 1). Tailored to the 2011-2012 CITRO cohort, this course benefited from the insights and experiences of five "veteran" CITRO students who, with UV-UF faculty, served as both instructors and mentors. Course content was a select subset of the initiative courses and dissemination activities, with an emphasis on forest-based communities and their resources. Most of the course took place in Ejido Tonalaco, learning from community members and practicing newly learned techniques. The final activity was a popular theater presentation to Tonalaco's primary and secondary students, allowing the cohort to share their learning with, and express gratitude to, the community. Finally, honoring their commitment to replicate learning opportunities, CITRO students of the 2010-2011 cohort assisted the 2011-2012 cohort to organize a Second Student Exchange Forum (Fig. 1).

\section{Student impacts}

\section{Diversity (across disciplines and individuals) as a strength}

The adapted collective student reflection presented at the SECOLAS conference in Spring 2012 (Fig. 2) highlighted the concept of diversity as a strength, which students described as both the greatest challenge of interdisciplinary 
studies and greatest success of their educational experience. The students framed the learning initiative as grounded in a holistic concept of conservation and natural resource management, crossing disciplinary frontiers and adopting multidisciplinary training as a route to a fuller understanding of realworld realities. The external evaluation also highlighted disciplinary integration for problem solving as an important student impact.

The 2012 student reflection also emphasized that beyond disciplinary diversity, the initiative "strengthened knowledge exchange between students and took advantage of the individual qualities of each student. That which could have represented knowledge gaps and obstacles to understanding, became raw materials for exchange and learning." Creating a safe environment that builds on what each adult already knows, and where each can excel in her/his own way, while gaining respect for what others have to offer, mimics the types of behavior and open attitudes needed in conservation practice (Manolis et al. 2008). Three years after the initiative, one student wrote: "The human factor was integrated into the educational process, rather than denying it." The 2012 student reflection noted that "The teaching-learning process itself was an education impregnated with values." To engage in "realworld" conservation activities, one must consider human values (Parsons and MacPherson, 2016). They are a key component of all human endeavors, and conservation and conservation education are no different.

\section{Individual and collective learning}

The 2012 student reflection emphasized complementarity between individual and collective learning and action. Individual appropriation of their own learning was considered a key learning innovation (Fig. 2). Each student was compelled to take control of his or her own educational process and to forge active and responsible learning attitudes.

Traditionally, graduate courses seek to impart knowledge and skills to foment professional growth of individual students. This type of individual learning was part of the initiative, but emphasis was on collective or social learning"learning that goes beyond the individual to include the social units and networks in which individuals interact" (Cundill et al. 2012, p. 16). As the students reflected in 2012, "during the entire experience, the initiative emphasized working together," which led to "achieving unexpected and enriching results in terms of training all members of the group, both students and instructors." Multiple activities in the two courses centered on group work (Table 2), but the two Student Exchange Fora were perhaps the most impactful learning opportunities. Fora organization was in the hands of the students - a situation that initially generated controversy and tension. UV faculty and administrators struggled to comprehend and accept student-led organization of a new event within the graduate program, particularly one that was open to other departments and the public. In turn, students were challenged to recognize the needs, interests, and culture of their graduate training institution. Students drew on negotiation skills learned in their Conflict Management course to work with CITRO administration to jointly execute a successful event.

In addition to fostering teamwork among students, collective learning extended beyond the UV campus. Learning was complemented and challenged by the realities of rural livelihoods, resource use and management, and the larger sociopolitical contexts in which these human-dominated landscapes are embedded. In reflecting on their experiences going "off campus" in the Conflict Management course, students reported that integrating experiential and practical classroom learning with stakeholder interactions, and then discussing their findings at a workshop with local scholars and practitioners, helped them to begin thinking of themselves as professionals, not just students. In the Spring 2012 presentation, students used the term practical (Fig. 2) to highlight the immediate application of classroom theory in their community interactions. These settings also were valuable for students to gain knowledge and experience in addressing often-conflicting local, regional, and national development and conservation goals. As reported in the external evaluation: "We learned a lot from the people in the communities, things you don't learn in books." Integrating local practitioners and communities institutionalizes grounded capacity building and elevates and incorporates the traditional knowledge and expertise they already possess into the learning process (Alexiades et al. 2013).

Working together to share their findings in both Tonalaco and El Conejo communities (Fig. 1) was also considered a highly impactful activity. According to the external evaluation, this was a new concept for most students and challenged them to develop and apply newly cultivated skills. Three years after the initiative, most students reported adopting results dissemination as a professional and academic norm, considering it "an important ethical component of conservation leadership." The external evaluation revealed an even broader impact of integrating communities: "for [students] the goal is not to go to the communities and just do research. They are more open now and appreciate the possibilities and responsibilities of a whole new world of collaboration." Practicing collaboration in a graduate program refines leadership skills, while simultaneously advancing advantageous linkages between academics and practitioners involved in day-to-day conservation and development (Kainer et al. 2006).

\section{Intertwined professional and personal growth}

In the 2012 reflection, students evaluated the success of their educational experience based on applications in both work and personal life. They noted that "merging these two was 
necessary in their professional lives, just as theory and practice came together in the educational experience." Concepts, skills, and attitudes learned and practiced in the Conflict Management course were often cited as examples that led to intertwined professional and personal growth. Empathic listening was key to detecting the source of problems and invariably cited in working toward resolution of both professional and personal conflicts. Three years after the initiative, one student noted that these skills gave him the ability "to reframe, questions and overcome walls of family conflicts that I have had to sort out." Another described using empathic listening while negotiating with a group opposing an environmental assessment. For another student, negotiation had become a daily part of his work, inspecting properties and identifying irregularities in natural resource exploitation. While managing socio-environmental conflict, he put into action what he learned about involving all stakeholders to search for solutions, and knowing how to handle difficult situations, such as when opposing parties are mired in threats and intimidation. A third student reported he was more open to dialogue and recognized the need to get to the bottom of the conflict.

\section{The concept of conservation leadership}

Students reported in the external evaluation that they possess a new conceptualization of leadership. They highlighted that "the leader is not the person who gives orders and says what to do" but rather "a person that can sit down and talk with people, a person who listens and dialogues to help others identify their needs, and a person that can help others get organized for positive and productive action." These statements mirrored those expressed during the 2011 StudentFaculty Retreat (Fig. 1). Faculty asked students to define the term "leadership" and to identify leadership characteristics required by natural resource management professionals. Students were initially uncomfortable and even rebelled at the idea that they were being groomed to become leaders. They associated the term "leader" with actions of one individual who sets an agenda and guides others through the process to achieve pre-defined goals. The external evaluation quoted one student: "I don't like to be a leader. I prefer to be an agent of change." Another took it further, reporting: "[The faculty] allowed us to be free and we enjoyed the freedom of creating, and in the process, we developed the required skills to be agents of change."

It was the intent of the initiative's pedagogy and governance to model this kind of collaborative leadership - to not just espouse a different kind of teaching approach but to demonstrate it. Three years after the initiative, three students stated that in their own teaching, whether targeting enrolled students in a formal educational setting or building capacity of community women or children, they had adopted elements of the educational innovations (Fig. 2).

\section{Institutional impacts, challenges, and opportunities}

Institutionalization of change within well-defined academic structures is challenging. Through 2012, external funding supported faculty and student exchanges, three UV courses, and diverse knowledge exchange activities (Fig. 1), but what happened afterward? How have our UV-UF collaborations continued and to what extent have institutional changes occurred at UV?

\section{Continued UV-UF collaborations}

Multiple collaborative activities and distinct accomplishments have been achieved following the initiative's completion (Fig. 1). UV faculty have realized short-term stays at UF, discussing their research projects and sharing their expertise in courses and conferences, and two UV masters students enjoyed a semester-long stay at UF. These interactions have been individually and collectively productive for UV participants and in turn, have enhanced the UF environment. For one UF faculty member, the enriching experience of working with UV Indigenous students inspired a 2016 field course in Mexico. Supported by a UV faculty member and graduate student, UF faculty and graduate students learned side-byside with faculty and undergraduate students from the Intercultural Maya University in the Mexican state of Quintana Roo. Collaborative UV-UF faculty-led investigations stimulated by our initiative resulted in joint publications (Ellis et al. 2014, Ellis et al. 2015) and conference presentations. UV faculty have served on UF graduate student committees and vice versa. Finally, our continued joint efforts were formalized institutionally with the 2016 signing of a 4year UF-UV Memorandum of Collaboration, which also signaled joint future interests.

\section{Institutionalizing change: challenges and opportunities}

Universities embody fairly rigid structures with well-defined processes. Introducing new curricula and pedagogical approaches, even if desired by administrators and faculty alike, is difficult. As noted by a UV administrator in the external evaluation: “... merging the partnership's activities into the core of CITRO's processes was also a challenge. This involved coordinating with multiple faculty members, matching agendas, and adapting to the institutional times. A fair amount of intelligence and diplomatic skills were required to smooth the way for the integration of faculty and project activities." This was evidenced with the Student Exchange Fora whereby students, who are notably absent in most university decisionmaking processes, were put in charge. Yet this activity and according to the external evaluation, the initiative in general, 
served as a catalyst "to develop and activate good networks of collaboration with different areas within UV which turned out to be fundamental for the success of this project." Maintaining institutional support for these democratic processes remains a challenge and instigating administrative change toward a democratization of educational processes and decision-making is a slow and delicate proposition, yet it occurs. In our case, many elements of the Conflict Management course (i.e., concepts and skills, pedagogical approach) were immediately adopted and adapted for a subsequent Community Development course that continues until today. Recent administrative changes have permitted greater internalization of several pedagogical aspects of the initiative into CITRO's graduate curriculum. In sum, beyond the structural and resource constraints of any university system exist people, who, with conviction and commitment, can pave a path toward individual and collective transformation.

\section{Concluding thoughts in training the next generation of conservation leaders}

The complementary, integrated quality of this initiative was viewed by students as its greatest virtue. Preparing students to deal with socio-environmental conflicts is also paramount. Effective leaders need to listen without judgment to those they dislike and disagree with, not just those in their philosophical camp. Learning to convene, listen, and negotiate (rather than simply convey and convince) prepares students to deal with conflicts inherent in conservation and emphasizes the value in enabling different voices and views for the benefit of conservation - the democratization of conservation and conservation leadership.

Finally, constant reflection allows for ongoing experimentation with learning, improvisation and adaptation of the teaching-learning processes and activities, and redirection of a program when necessary. Training student and educators to explicitly integrate and conduct reflection exercises goes a long way to extract lessons learned and conceptualize them so they can then be used for the next teaching opportunity. Publishing a popular synopsis of the initiative in Spanish (López Binnqüist et al. 2011) and writing this paper, coauthored by five students and six faculty participants, provided additional reflection opportunities.

Our case contributes to the emerging novel pedagogical approaches in the environmental and sustainability fields that incorporate more critical teaching methods (Gosselin et al. 2016, Scholz et al. 2018). The direct and active involvement of students in the construction and analysis of pedagogic platforms, however, constitutes a relatively unique experience (Lips-Wiersma and Allan, 2018), especially for students of diverse origins, backgrounds, and experiences such as ours. Our case may also be distinguished by its collaborative design and implementation by universities in the Global North and South, targeting students in a Mexican university. In general, the literature shows a steady incremental interest from universities and individual teachers to innovate and challenge existing educational norms to consider contemporary contexts and local needs (Gosselin et al. 2016). These innovations imply not only curricula modification, competencies, and infrastructure (Vincent et al. 2016) but also new ways of teaching through individual and collective reflection, respect, and listening - all crucial conditions toward democratization, the basis of our educational platform. The window of innovation remains wide open to explore pedagogical processes and outcomes in different regions of the world as collaborations across and within universities and scholars of different regions evolve and as the social and environmental context demands new teaching content and dynamics. Ultimately, we hope that this case analysis and its pedagogical elements can be used by other institutions and educators to train conservation leaders.

Acknowledgements We thank the people and authorities of Tonalaco and El Conejo communities for their hospitality as well as the Departamento de Vinculación of the Universidad Veracruzana for supporting activities in El Conejo. This initiative was funded by the United States-Mexico Training, Internships, Exchanges, and Scholarships (TIES) Higher Education Program (HED) of the U.S. Agency for International Development (USAID) (2009-2012) and two awards (2010-2011) to JLD and KAK through the U.S. Department of State Fulbright García Robles Scholar Program. Open Access to this article was funded by the Universidad Veracruzana and the University of Florida's Open Access Publishing Fund, Center for Latin American Studies, and School of Forest Resources and Conservation.

Open Access This article is distributed under the terms of the Creative Commons Attribution 4.0 International License (http:// creativecommons.org/licenses/by/4.0/), which permits unrestricted use, distribution, and reproduction in any medium, provided you give appropriate credit to the original author(s) and the source, provide a link to the Creative Commons license, and indicate if changes were made.

Publisher's note Springer Nature remains neutral with regard to jurisdictional claims in published maps and institutional affiliations.

\section{References}

Alexiades MN, Peters CM, Laird SA, López Binnqüist C, Negreros Castillo P (2013) The missing skill set in community management of tropical forests. Conserv Biol 27:635637. https://doi.org/10.1111/cobi.12040

Anderson C (2010) Presenting and evaluating qualititative research. Am J Pharm Educ 74(8). https://doi.org/10.5688/aj7408141

Bawa KS, Kress WJ, Nadkarni NM (2004) Beyond paradise - meeting the challenges in tropical biology in the 21 st century. Biotropica 36(3):276-284

Bonine K, Reid J, Dalzen R (2003) Training and education for tropical conservation. Conserv Biol 17:1209-1218. https://doi.org/10.1046/ j.1523-1739.2003.01754.x 
Camou-Guerrero A, Castillo A, García-Frapolli E (2013) Procesos de formación educativa interdisciplinaria: miradas desde las ciencias ambientales. Universidad Nacional Autonóma de México, Mexico City, pp 177-186

Cannon JR, Dietz JM, Dietz LA (1996) Training conservation biologists in human interaction skills. Conserv Biol 10:1277-1282. https://doi. org/10.1046/j.1523-1739.1996.10041277.x

CONANP (Comisión Nacional de Áreas Naturales Protegidas) (2015) Programa de Manejo del Parque Nacional Cofre de Perote o Nauhcampatépetl. CONANP, Mexico City, p 18

Corcoran PB, Walker KE, Wals AE (2004) Case studies, make-your-case studies, and case stories: a critique of case-study methodology in sustainability in higher education. Environ Educ Res 10(1):7-21. https://doi.org/10.1080/1350462032000173670

Courter JR (2012) Graduate students in conservation biology: bridging the research implementation gap. J Nat Conserv 20:62-64. https:// doi.org/10.1016/j.jnc.2011.10.001

Cundill G, Cumming GS, Biggs D, Fabricius C (2012) Soft systems thinking and social learning for adaptive management. Conserv Biol 26:13-20. https://doi.org/10.1111/j.1523-1739.2011.01755.x

Duchelle AE, Biedenweg K, Lucas C, Virapongse A, Radachowsky J, Wojcik DJ, Londres M, Bartels W, Alvira D, Kainer KA (2009) Graduate students and knowledge exchange with local stakeholders: possibilities and preparation. Biotropica 41:578-585. https://doi. org/10.1111/j.1744-7429.2009.00563.x

Ellis EA, Kainer K, Sierra H, Negreros-Castillo P, DiGiano M (2014) Community based forest management in Quintana Roo. In: Forests under pressure: local responses to global issues. International Union of Forest Research Organizations (IUFRO). World Forests, Society and Environment (WFSE). Vantaa, Finland. pp 131-151

Ellis EA, Kainer K, Sierra H, Negreros-Castillo P, Rodriguez-Ward D, DiGiano M (2015) Endurance and adaptation of community forest management in Quintana Roo, México. Forests 6:4295-4327. https://doi.org/10.3390/f6114295

Fisher B, Balmford A, Green RE, Trevelyan R (2009) Conservation science training: the needs for an extra dimension. Oryx 43:361-363. https://doi.org/10.1017/S0030605309990263

Flyvbjerg B (2006) Five misunderstandings about case-study research. Qual Inq 12(2):219-245. https://doi.org/10.1177/ 1077800405284363

Freire P (1970) Pedagogy of the oppressed (M Bergman Ramos, translator). Herder and Herder, New York, p 182

García-Romero A, Montoya Y, Ibarra M, Garza G (2010) Economía y política en la evolución contemporánea de los usos del suelo y la deforestación en México: el caso del volcán Cofre de Perote. Interciencia 35:321-328

Gosselin D, Vincent S, Boone C, Danielson A, Parnell R, Pennington D (2016) Introduction to the special issue: negotiating boundaries: effective leadership of interdisciplinary environmental and sustainability programs. J Environ Stud Sci 6(2):268-274. https://doi.org/ 10.1007/s13412-015-0357-2

Holling CS, Meffe GK (1996) Command and control and the pathology of natural resource management. Conserv Biol 10(2):328-337

Kainer KA, Schmink M, Covert H, Stepp JR, Bruna EM, Dain JL, Espinosa S, Humphries S (2006) A graduate education framework for tropical conservation and development. Conserv Biol 20:3-13. https://doi.org/10.1111/j.1523-1739.2006.00356.x

Kolb DA (1984) Experiential learning. Prentice Hall, Englewood Cliffs

Lips-Wiersma M, Allan H (2018) The student voice in critical leadership education: an exploration of student-faculty partnership learning in sustainability education. Leadership 14(2):240-255
López-Binnqüist C, Kainer KA, Ellis EA, Dain JL, Covert HH, Negreros-Castillo P (2011) La educación como base para la conservación, experiencias dentro y fuera del aula. Jarocho Cuántico, la jornada Veracruz. 3

Manolis JC, Chan KM, Finkelstein ME, Stephens S, Nelson CR, Grant JB, Dombech MP (2008) Leadership: a new frontier in conservation science. Conserv Biol 23(4):879-886. https://doi.org/10.1111/j. 1523-1739.2008.01150.x

Mascia MB, Brosius JP, Dobson TA, Forbes BC, Horowitz L, McKean MA, Turner NJ (2003) Conservation and the social sciences. Conserv Biol 17:649-650. https://doi.org/10.1046/j. 1523-1739.2003.01738.x

Meffe GK, Ehrenfield D, Noss RF (2006) Conservation biology at twenty. Conserv Biol 20:595-596. https://doi.org/10.1111/j. 1523-1739.2006.00441.x

Moon K, Blackman D (2014) A guide to understanding social science research for natural scientists. Conserv Biol 28:1167-1177. https:// doi.org/10.1111/cobi.12326

Moore CW (2014) The mediation process: practical strategies for resolving conflict, 4th edn. Jossey-Bass, San Francisco, p 96

Moreno-Casasola P, Sánchez Ríos G (1990) La enseñanza de la ecología en México. Revista Ciencias 4:96-111

Muir MJ, Schwartz MW (2009) Academic research training for a nonacademic workplace: a case study of graduate student alumni who work in conservation. Conserv Biol 23:13571368. https://doi.org/10.1111/j.1523-1739.2009.01325.x

Parsons ECM, MacPherson R (2016) Have you got what it takes? Looking at skills and needs of the modern marine conservation practitioner. J Environ Stud Sci 6(3):515-519. https:// doi.org/10.1007/s13412-015-0353-6

Pérez HE (2005) What students can do to improve graduate education in conservation biology. Conserv Biol 19:2033-2035

Pietri DM, Gurney GG, Benitez-Vina N, Kuklok A, Maxwell SM, Whiting L, Vina MA, Jenkins LD (2013) Practical recommendations to help students bridge the researchimplementation gap and promote conservation. Conserv Biol 27:958-967. https://doi.org/10.1111/cobi.12089

Sandbrook C, Adams WM, Büscher B, Vira B (2013) Social research and biodiversity conservation. Conserv Biol 27:1487-1490. https://doi. org/10.1111/cobi.12141

Scholz RW, Yarime M, Shiroyama H (2018) Global leadership for social design: theoretical and educational perspectives. Sustain Sci 13: 447-464. https://doi.org/10.1007/s11625-017-0454-0

Sievanen L, Campbell LM, Leslie HM (2012) Challenges to interdisciplinary research in ecosystem-based management. Conserv Biol 26: 315-323. https://doi.org/10.1111/j.1523-1739.2011.01808.x

Toomey A (2016) What happens at the gap between knowledge and practice? Spaces of encounter and misencounter between environmental scientists and local people. Ecol Soc 21(2):28. https://doi. org/10.5751/ES-08409-210228

Vincent S, Focht W (2011) Interdisciplinary environmental education: elements of field identity and curriculum design. J Environ Stud Sci 1:14-35. https://doi.org/10.1007/s13412-011-0007-2

Vincent S, Roberts JT, Mulkey S (2016) Interdisciplinary environmental and sustainability education: islands of progress in a sea of dysfunction. J Environ Stud Sci 6(2):418-424. https:// doi.org/10.1007/s13412-015-0279-Z 